\title{
Effect of Soil Application of Zinc on Growth, Yield and Zinc Concentration in Rice Varieties
}

\author{
M. Rafiqul Islam, Abida Sultana, M. Jahiruddin, and Shofiqul Islam
}

\section{ABSTRACT}

Zinc $(\mathrm{Zn})$ deficiency is widespread nutrient disorder in lowland rice growing areas in Asia, especially in Bangladesh. Intensive cropping with modern varieties causes depletion of inherent nutrient reserves in soils. The application of $\mathrm{Zn}$ fertilizers results in higher crop productivity and increases $\mathrm{Zn}$ concentration in crops. A field experiment was conducted to evaluate the effect of $\mathrm{Zn}$ application on growth, yield, and grain- $\mathrm{Zn}$ concentration in eight varieties of rice. The experiment was laid out in a split plot design with a distribution of $\mathrm{Zn}$ rates $\left(0 \mathrm{~kg} \mathrm{ha}^{-1}\right.$ and $3 \mathrm{~kg} \mathrm{ha}^{-1}$ from $\left.\mathrm{ZnO}\right)$ to the main plots and rice varieties (BRRI dhan49, BRRI dhan52, BRRI dhan56, BRRI dhan57, Kalizira, Biroin, Gainja and Khirshapath) to the sub-plots. Zinc application improved effective tillers hill- $^{-1}$, grains panicle ${ }^{-1}$ and 1000-grain weight which impacted the grain yield of rice. Among the eight rice varieties, a significant increase of grain yield was recorded in BRRI dhan49, BRRI dhan52, BRRI dhan56 and BRRI dhan57 due to application of Zn. Zinc concentration of grain significantly increased in all rice varieties except Biroin. The highest grain-Zn concentration $\left(19.1 \mathrm{mg} \mathrm{kg}^{-1}\right)$ was noted in BRRI dhan57 with $3 \mathrm{~kg} \mathrm{ha}^{-1} \mathrm{Zn}$ and the lowest value $\left(11.3 \mathrm{mg} \mathrm{kg}^{-1}\right)$ was observed in BRRI dhan52 without $\mathrm{Zn}$ application. The highest percent increase of grain $\mathrm{Zn}$ concentration over control was obtained in high yielding rice variety BRRI dhan 49 and the lowest $\mathrm{Zn}$ concentration was found in local rice variety Biroin.

Keywords: Grain Yield, Rice Variety, Zinc, Zinc Concentration, Yield Component.
Submitted : November 30, 2021

Published : December 29, 2021

ISSN: $2684-1827$

DOI: $10.24018 /$ ejfood.2021.3.6.425

\section{Rafiqul Islam}

Department of Soil Science, Bangladesh Agricultural University, Bangladesh.

(e-mail: mrislam58@bau.edu.bd)

Abida Sultana

Department of Soil Science, Bangladesh Agricultural University, Bangladesh.

M. Jahiruddin

Department of Soil Science, Bangladesh Agricultural University, Bangladesh.

(e-mail: m_jahiruddin@yahoo.com)

\section{Shofiqul Islam*}

Department of Soil Science, Bangladesh Agricultural University, Bangladesh.

(e-mail: sislam84@gmail.com)

*Corresponding Author

\section{INTRODUCTION}

Zinc is an essential trace element for life, responsible for the formation of a large number of enzymes and also plays an essential role, particularly in children, including delays in physical growth, immune system function, DNA transcription etc. [1], [2]. One third of the world populations in the developing countries suffers from $\mathrm{Zn}$ deficiency, which is due to inadequate dietary intake [2], [3]. Zinc deficiency reduces immune system, reproductive function, and stunted growth of human [4], [3]. Zinc deficiency in plants inhibits growth and is one of the nutrients influencing rice production in many regions of the world [5], [6]. Among the micronutrients, $\mathrm{Zn}$ deficiency one of the most widespread nutrient disorders in lowland rice areas in Asia [7]-[9]. Rice is a major food source consumed by about $50 \%$ of the world's population and constitutes $67 \%$ of the daily diet and some extent of proteins to humans [10], [11]. Zinc deficiency is an eminent health problem in human populations those consuming rice as their staple food [12], [13]. The average daily rice consumption for adults in Bangladesh of $370 \mathrm{~g}$ which is one of the world's highest per capita rice consumptions [14], [15]. Therefore, even a small increase in the nutritive value of rice can be highly significant for human nutrition in Bangladesh [16], [17]. The main reason of $\mathrm{Zn}$ deficiency in plant is the precipitation or adsorption of $\mathrm{Zn}$ with various soil components, depending on $\mathrm{pH}$, organic matter, pedogenic oxides and redox potential [18]. The application of Zn may increase grain yield, dry matter content and $\mathrm{Zn}$ concentration in rice [19], [20]. Rice varieties showed significant variation in $\mathrm{Zn}$ tolerance [20] and in $\mathrm{Zn}$ content in rice grains [21]. Rice variety enriched with $Z n$ may be a good source of $\mathrm{Zn}$ for those $\mathrm{Zn}$ deficient people. For this, biofortification of $\mathrm{Zn}$ in rice has emerged as a possible solution to alleviate malnutrition [22], [16], [23]. The practice of intensive cropping with modern crop varieties is a major endeavor of crop production in Bangladesh. This in turn causes a marked depletion of inherent nutrient status in soils. Increasing the $\mathrm{Zn}$ concentration of food crops, resulting in higher crop production and improved human health is an important global challenge. Therefore, a field experiment was conducted to study the effect of $\mathrm{Zn}$ application on growth, yield, and grain- $\mathrm{Zn}$ concentration of four modern and four local varieties of rice.

\section{MATERIALS AND METHODS}

This study was undertaken at the Soil Science Field Laboratory, Bangladesh Agricultural University, during the T. aman season (August to December) to evaluate the soil application of $\mathrm{Zn}$ on growth, yield, and grain $\mathrm{Zn}$ concentration of different varieties of rice. The experimental 
area comprises the Agro Ecological Zone 9 Old Brahmaputra Flood Plain. Texturally the soil was silt loam having $\mathrm{pH}$ 6.3, total $\mathrm{N} 0.085 \%$, organic matter $1.46 \%$, available $\mathrm{P} 12.6 \mathrm{mg}$ $\mathrm{kg}^{-1}$, available S $12.8 \mathrm{mg} \mathrm{kg}^{-1}$, exchangeable $\mathrm{K} 0.105 \mathrm{me} \%$ and available $\mathrm{Zn} 0.70 \mathrm{mg} \mathrm{kg}^{-1}$. There were two rates of $\mathrm{Zn}$ viz. 0 and $3 \mathrm{~kg} \mathrm{Zn} \mathrm{ha}{ }^{-1}$ were applied from $\mathrm{ZnO}$. The experiment was laid out in a split plot design with 3 replications and each treatment having $\mathrm{Zn}$ rates in the main plot and rice varieties in the sub plots. The four high yielding rice varieties viz. BRRI dhan49, BRRI dhan52, BRRI dhan56 and BRRI dhan57, and four local rice varieties viz. Kalizira, Biroin, Gainja and Khirshapath were used in the experiment. There were altogether 16 treatments. The size of each plot was $2 \times 3 \mathrm{~m}$ and plots were separated from each other by ails $(30 \mathrm{~cm})$. All the plots received $75 \mathrm{~kg} \mathrm{~N}, 16 \mathrm{~kg} \mathrm{P}, 42 \mathrm{~kg} \mathrm{~K}$ and $15 \mathrm{~kg} \mathrm{~S} \mathrm{ha}^{-1}$ from urea, triple super phosphate, muriate of potash and gypsum, respectively. The full dose of triple super phosphate, muriate of potash, gypsum and $\mathrm{ZnO}$ were applied at the time of final land preparation. The urea was applied in 3 equal splits at 7, 30 and 60 days after transplanting. Thirtythree days old seedlings were transplanted in the experimental plots and each hill consists of 3 seedlings maintaining in an equal distance $(20 \times 20 \mathrm{~cm})$ from row to row and from plant to plant. Intercultural operations were employed as and when necessary. The crop was harvested in different dates at maturity. The yield and yield contributing characters (plant height, effective tillers hill ${ }^{-1}$, filled grains, 1000 grain weight) of all rice varieties were recorded. The grain samples were oven dried at $65^{\circ} \mathrm{C}$ until constant weight. The grain yields were expressed in $\mathrm{t} \mathrm{ha}^{-1}$ at $14 \%$ moisture basis while the straw yield on sun dry basis. The grain $\mathrm{Zn}$ content was determined by digesting the grain samples with the diacid mixture $\left(\mathrm{HNO}_{3}: \mathrm{HClO}_{4}\right.$ in the ratio of $\left.3: 1\right)$. Zinc was determined from this digest by Atomic Absorption Spectrophotometer (AAS). The analysis of variance for crop parameters and also for nutrient contents in grain was done following the principles of $F$ statistics. The mean results in case of significant F-value were compared by the Duncan's Multiple Range Test (DMRT) [24].

\section{RESULTS AND DISCUSSIONS}

\section{A. Growth and Yield Parameters}

\section{1) Plant height}

There was no significant variation of plant height in different rice varieties due to soil application of $\mathrm{Zn}$ (Table I). Plant height of $86.33 \mathrm{~cm}$ was found rice plants without any $\mathrm{Zn}$ application and $90.72 \mathrm{~cm}$ with $3 \mathrm{~kg} \mathrm{Zn} \mathrm{ha} \mathrm{kg}^{-1}$ application. Khirshapath was the tallest $(107.90 \mathrm{~cm})$ plant which was statistically similar with Biroin and Gainja. Kalizira had the shortest $(73.93 \mathrm{~cm})$ plants which was also statistically similar with BRRI dhan52, BRRI dhan56 and BRRI dhan57. The interaction effect of different rates of $\mathrm{Zn}$ and different varieties of rice was statistically significant (TABLE II). The plant height of eight rice varieties over the two $\mathrm{Zn}$ rates ranged from $72.03 \mathrm{~cm}$ in BRRI dhan 49 with $0 \mathrm{~kg} \mathrm{Zn} \mathrm{ha}^{-1}$ to $108.79 \mathrm{~cm}$ in Biroin with $3 \mathrm{~kg} \mathrm{ha}^{-1} \mathrm{Zn}$ treatment. At two $\mathrm{Zn}$ levels, the variety Khirshapath showed the tallest plant and BRRI dhan49 showed the shortest plant. There was no statistically significant variation of plant height with the same variety due to application of $0 \mathrm{~kg} \mathrm{ha}^{-1}$ and $3 \mathrm{~kg} \mathrm{ha}^{-1} \mathrm{Zn}$ but other varieties.

\section{2) Effective tillers hill $^{-1}$}

Tillering capacity is an important component of grain yield of rice. Increased number of effective tillers per plant can result in higher yield of crop [25]. Zinc application showed insignificant variation in case of effective tillers hill ${ }^{1}$ (Table I). The number of effective tillers hill ${ }^{-1}$ was 7.07 without $\mathrm{Zn}$ application and 7.99 with $\mathrm{Zn}$ application. The different varieties of rice varied significantly in terms of number of effective tillers hill ${ }^{-1}$, which ranged from 6.58 to 8.63 (Table II). The highest number of effective tillers hill ${ }^{-1}$ of 8.63 observed in BRRI dhan57 was statistically identical to those found in BRRI dhan49, BRRI dhan52 and BRRI dhan56. The lowest number (6.58) of effective tillers hill ${ }^{-1}$ was obtained in Kalizira which was statistically similar with those observed in Biroin, Gainja and Khirsapath. Similar findings have been reported which showed that application of $\mathrm{Zn}$ increased number of tillers hill ${ }^{-1}$ [1]. This result is also consistent with the study showed that application of $\mathrm{Zn}$ increased the number of effective tillers hill ${ }^{-1}$ [26]. The interaction effect of different rates of $\mathrm{Zn}$ application and different varieties on number of effective tillers hill ${ }^{-1}$ was statistically significant (Table II). The formation of effective tillers hill ${ }^{-1}$ due to application of $3 \mathrm{~kg} \mathrm{ha}^{-1}$ of $\mathrm{Zn}$ in all varieties was higher than that of $\mathrm{Zn}$ control treatments.

\section{3) Filled grains panicle ${ }^{-1}$}

The number of filled grains panicle ${ }^{-1}$ in rice varieties was found to be insignificant due to soil application of $\mathrm{Zn}$ (Table I). The number of filled grains panicle ${ }^{-1}$ was 65.11 when no $\mathrm{Zn}$ was applied, and it was 70.37 with $3 \mathrm{~kg} \mathrm{ha}^{-1} \mathrm{Zn}$ application. BRRI dhan 49 showed the highest number of filled grains panicle ${ }^{-1}$ (87.54) which was statistically similar to those found in BRRI dhan52, BRRI dhan56 and BRRI dhan57. The interaction of two levels of $\mathrm{Zn}$ with different varieties showed significant variation in terms of filled grains panicle $^{-1}$ of rice (Table II). The highest number of filled grains panicle ${ }^{-1}$ (92.34) was found in BRRI dhan49 treated with $3 \mathrm{~kg} \mathrm{ha}^{-1} \mathrm{Zn}$ while the lowest number of filled grains panicle $^{-1}$ (45.77) was recorded in Kalizira grown without Zn application. The local rice varieties had the lower number of filled grains panicle ${ }^{-1}$ compared to those of modern rice varieties. The varieties Kalizira, Biroin, Gainja and Khirsapath were statistically similar in both 0 and $3 \mathrm{~kg} \mathrm{ha}^{-1}$ $\mathrm{Zn}$ applications. Increased rate of $\mathrm{Zn}$ significantly increased the number of grains panicle ${ }^{-1}$ of rice [27] which was similar with the present study. Previous studies confirmed that $\mathrm{Zn}$ fertilizer enhanced the number of grains panicle ${ }^{-1}$ through improving physiological processes of the crop such as photosynthesis and nutrient translocation [28].

\section{4) 1000-grain weight}

Result represented in Table I showed that the 1000-grain weight of rice was significantly increased due to application of $\mathrm{Zn}$. The 1000-grain weight was found $17.25 \mathrm{~g}$ with $3 \mathrm{~kg}$ $\mathrm{ha}^{-1} \mathrm{Zn}$ application and $17.12 \mathrm{~g}$ without $\mathrm{Zn}$ application. Among all the rice varieties, the local rice varieties had lower 1000-grain weight compared to those of the modern rice varieties. The highest 1000-grain weight was observed in BRRI dhan52 (25.07 g) and the lowest weight was observed in Khirsapath (10.88 g). The interaction of $\mathrm{Zn}$ and varieties was statistically significant in case of 1000-grain weight (TABLE II). The highest 1000-grain weight (25.07 g) was 
observed in BRRI dhan52 with $3 \mathrm{~kg} \mathrm{ha}^{-1} \mathrm{Zn}$ application and the lowest $(10.88 \mathrm{~g})$ was in Khirsapath without $\mathrm{Zn}$ application. There was no statistically significant variation of 1000-grain weight due to application of $3 \mathrm{~kg} \mathrm{ha}^{-1} \mathrm{Zn}$ and without $\mathrm{Zn}$ within the same variety, but variations were observed among the varieties. Proper Zn application rates increased grain weight by allowing $\mathrm{Zn}$ to participate more efficiently in the various metabolic processes engaged in good seed production [29].

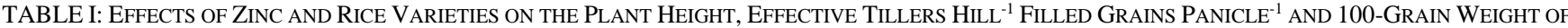

\begin{tabular}{|c|c|c|c|c|}
\hline Factors & Plant height $(\mathrm{cm})$ & $\begin{array}{l}\text { Effective tillers hill }^{-1} \\
\text { (no.) }\end{array}$ & $\begin{array}{l}\text { Filled grains } \\
\text { panicle }^{-1}(\mathrm{~cm})\end{array}$ & $\begin{array}{c}\text { 1000-grain wt. } \\
(\mathrm{g})\end{array}$ \\
\hline \multicolumn{5}{|c|}{$\mathrm{Zn}$ rates $\left(\mathrm{kg} \mathrm{ha}^{-1}\right)$} \\
\hline $\mathrm{Zn}_{0}$ & 86.33 & 7.07 & 65.11 & 17.12 \\
\hline $\mathrm{Zn}_{3}$ & 90.72 & 7.99 & 70.37 & 17.25 \\
\hline $\mathrm{CV}(\%)$ & 5.70 & 8.28 & 10.48 & 6.99 \\
\hline Level of significance & NS & NS & NS & $* * *$ \\
\hline \multicolumn{5}{|c|}{ Varieties } \\
\hline BRRI dhan 49 & $74.97 \mathrm{~b}$ & $8.47 \mathrm{a}$ & $87.54 a$ & $18.44 \mathrm{c}$ \\
\hline BRRI dhan 52 & $79.49 \mathrm{~b}$ & $7.78 \mathrm{ab}$ & $85.79 \mathrm{a}$ & $25.03 \mathrm{a}$ \\
\hline BRRI dhan56 & $82.03 \mathrm{~b}$ & $7.77 \mathrm{ab}$ & $82.32 \mathrm{a}$ & $22.68 b$ \\
\hline BRRI dhan57 & $76.45 \mathrm{~b}$ & $8.63 \mathrm{a}$ & $83.72 \mathrm{a}$ & $14.16 \mathrm{ef}$ \\
\hline Kalizira & $73.93 b$ & $6.58 \mathrm{c}$ & $46.87 \mathrm{~b}$ & $12.74 \mathrm{fg}$ \\
\hline Biroin & $107.23 \mathrm{a}$ & $7.07 \mathrm{bc}$ & $56.12 \mathrm{~b}$ & $17.50 \mathrm{~cd}$ \\
\hline Gainja & $106.17 \mathrm{a}$ & $6.87 \mathrm{bc}$ & $47.72 \mathrm{~b}$ & $16.00 \mathrm{de}$ \\
\hline Khirshapath & $107.90 \mathrm{a}$ & $7.07 \mathrm{bc}$ & $51.84 \mathrm{~b}$ & $10.89 \mathrm{~g}$ \\
\hline $\mathrm{CV}(\%)$ & 7.70 & 8.28 & 9.48 & $6.99^{\circ}$ \\
\hline Level of sionificance & $* *$ & $* *$ & $* *$ & $* *$ \\
\hline
\end{tabular}

In a column, the figures having common letter(s) do not differ significantly at $5 \%$ level of probability. $\mathrm{CV}=$ Coefficient of variation, $* *=\mathrm{P}<0.001 ; \mathrm{NS}=\mathrm{Not}$ significant.

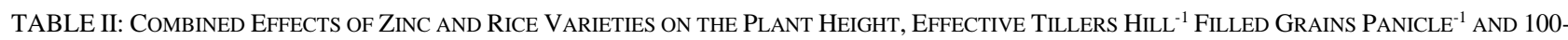
GRAIN WEIGHT OF DIFFERENT VARIETIES OF RICE

\begin{tabular}{|c|c|c|c|c|c|}
\hline Variety & $\mathrm{Zn}$ rates & $\begin{array}{l}\text { Plant height } \\
(\mathrm{cm})\end{array}$ & $\begin{array}{l}\text { Effective tillers hill } \\
\text { (no.) }\end{array}$ & $\begin{array}{l}\text { Filled grains panicle }{ }^{-1} \\
(\mathrm{~cm})\end{array}$ & $\begin{array}{l}1000 \text { grain wt. } \\
(\mathrm{g})\end{array}$ \\
\hline \multirow[t]{2}{*}{ BRRI dhan49 } & $\mathrm{Zn}_{0}$ & $72.03 \mathrm{c}$ & $7.93 \mathrm{bcd}$ & $82.73 \mathrm{ab}$ & $18.42 \mathrm{c}$ \\
\hline & $\mathrm{Zn}_{3}$ & $77.91 \mathrm{c}$ & $9.00 \mathrm{ab}$ & $92.34 \mathrm{a}$ & $18.47 \mathrm{c}$ \\
\hline \multirow[t]{2}{*}{ BRRI dhan 52} & $\mathrm{Zn}_{0}$ & $74.97 \mathrm{c}$ & $7.23 \mathrm{cdef}$ & $81.20 \mathrm{ab}$ & $25.00 \mathrm{a}$ \\
\hline & $\mathrm{Zn}_{3}$ & $84.01 \mathrm{abc}$ & $8.33 \mathrm{abc}$ & $90.37 \mathrm{ab}$ & $25.07 \mathrm{a}$ \\
\hline \multirow[t]{2}{*}{ BRRI dhan56 } & $\mathrm{Zn}_{0}$ & $78.00 \mathrm{c}$ & $7.20 \mathrm{cdef}$ & $77.80 \mathrm{~b}$ & $22.75 b$ \\
\hline & $\mathrm{Zn}_{3}$ & $86.06 \mathrm{abc}$ & $8.33 \mathrm{abc}$ & $86.84 \mathrm{ab}$ & $22.60 \mathrm{~b}$ \\
\hline \multirow[t]{2}{*}{ BRRI dhan57 } & $\mathrm{Zn}_{0}$ & $72.87 \mathrm{c}$ & $8.10 \mathrm{abcd}$ & $79.53 \mathrm{ab}$ & $14.13 \mathrm{ef}$ \\
\hline & $\mathrm{Zn}_{3}$ & $80.02 b c$ & $9.17 \mathrm{a}$ & $87.90 \mathrm{ab}$ & $14.20 \mathrm{ef}$ \\
\hline \multirow[t]{2}{*}{ Kalizira } & $\mathrm{Zn}_{0}$ & $73.40 \mathrm{c}$ & $6.17 f$ & $45.77 \mathrm{c}$ & $12.75 \mathrm{fg}$ \\
\hline & $\mathrm{Zn}_{3}$ & $74.45 c$ & 7.00def & $47.97 \mathrm{c}$ & $12.73 \mathrm{fg}$ \\
\hline \multirow[t]{2}{*}{ Biroin } & $\mathrm{Zn}_{0}$ & $105.67 \mathrm{ab}$ & $6.63 \mathrm{ef}$ & $55.37 \mathrm{c}$ & $17.50 \mathrm{~cd}$ \\
\hline & $\mathrm{Zn}_{3}$ & $108.79 a$ & $7.50 \mathrm{cde}$ & $56.87 \mathrm{c}$ & $17.50 \mathrm{~cd}$ \\
\hline \multirow[t]{2}{*}{ Gainja } & $\mathrm{Zn}_{0}$ & $105.67 \mathrm{ab}$ & $6.63 \mathrm{ef}$ & $47.30 \mathrm{c}$ & $16.00 \mathrm{de}$ \\
\hline & $\mathrm{Zn}_{3}$ & $106.67 \mathrm{a}$ & 7.10def & $48.14 \mathrm{c}$ & $16.00 \mathrm{de}$ \\
\hline \multirow[t]{2}{*}{ Khirshapath } & $\mathrm{Zn}_{0}$ & $108.00 \mathrm{a}$ & $6.63 \mathrm{ef}$ & $51.17 \mathrm{c}$ & $10.88 \mathrm{~h}$ \\
\hline & $\mathrm{Zn}_{3}$ & $107.81 \mathrm{a}$ & $7.50 \mathrm{cde}$ & $52.51 \mathrm{c}$ & $11.40 \mathrm{gh}$ \\
\hline CV $(\%)$ & & 6.34 & 8.28 & 7.48 & 6.99 \\
\hline $\begin{array}{c}\text { Level of } \\
\text { significance }\end{array}$ & & $* *$ & $* *$ & $* *$ & $* *$ \\
\hline
\end{tabular}

In a column, the figures having common letter(s) do not differ significantly at $5 \%$ level of probability. $\mathrm{CV}=\mathrm{Coefficient}$ of variation $* *=\mathrm{P}<0.01$

TABLE III: EFFECTS OF ZINC AND RICE VARIETIES ON THE GRAIN YIELD, STRAW YIELD AND GRAIN ZINC CONCENTRATION OF DIFFERENT VARIETIES

\begin{tabular}{|c|c|c|c|}
\hline \multicolumn{4}{|c|}{ OF RICE } \\
\hline Factors & Grain yield $\left(\mathrm{t} \mathrm{ha}^{-1}\right)$ & Straw yield $\left(\mathrm{t} \mathrm{ha}^{-1}\right)$ & Zn concentration $\left(\mathrm{mg} \mathrm{kg}^{-1}\right)$ \\
\hline \multicolumn{4}{|c|}{ Zn rates $\left(\mathrm{kg} \mathrm{ha}^{-1}\right)$} \\
\hline $\mathrm{Zn}_{0}$ & $3.34 \mathrm{~b}$ & $4.53 b$ & $13.74 b$ \\
\hline $\mathrm{Zn}_{3}$ & $3.72 \mathrm{a}$ & $5.02 \mathrm{a}$ & $16.62 \mathrm{a}$ \\
\hline $\mathrm{CV}(\%)$ & 6.87 & 6.59 & 8.90 \\
\hline Level of significance & $*$ & $* *$ & $* *$ \\
\hline \multicolumn{4}{|c|}{ Varieties } \\
\hline BRRI dhan49 & $4.85 \mathrm{a}$ & $4.90 \mathrm{bc}$ & $13.87 \mathrm{bcd}$ \\
\hline BRRI dhan52 & $4.32 b$ & $4.64 \mathrm{c}$ & $12.66 \mathrm{~d}$ \\
\hline BRRI dhan56 & $4.19 b$ & $4.67 \mathrm{c}$ & $13.69 \mathrm{~cd}$ \\
\hline BRRI dhan57 & $3.29 \mathrm{c}$ & $3.66 \mathrm{~d}$ & $17.08 \mathrm{a}$ \\
\hline Kalizira & $2.60 \mathrm{~d}$ & $4.89 b c$ & $16.21 \mathrm{ab}$ \\
\hline Biroin & $3.09 \mathrm{c}$ & $5.61 \mathrm{a}$ & $15.92 \mathrm{abc}$ \\
\hline Gainja & $3.03 \mathrm{c}$ & $5.28 \mathrm{ab}$ & 14.78abcd \\
\hline Khirshapath & $2.86 \mathrm{~cd}$ & $4.56 \mathrm{c}$ & $17.22 \mathrm{a}$ \\
\hline $\mathrm{CV}(\%)$ & 6.87 & 6.59 & 8.90 \\
\hline Level of significance & $* *$ & $* *$ & $* *$ \\
\hline
\end{tabular}

In a column, the figures having common letter(s) do not differ significantly at $5 \%$ level of probability. CV $=$ Coefficient of variation, $* *=\mathrm{P}<0.01$. 
European Journal of Agriculture and Food Sciences www.ejfood.org

TABLE IV: COMBINED EFFECTS OF ZINC AND RICE VARIETIES ON THE GRAIN YIELD, STRAW YIELD AND GRAIN ZINC CONCENTRATION OF DIFFERENT

\begin{tabular}{|c|c|c|c|c|}
\hline \multicolumn{5}{|c|}{ VARIETIES OF RICE } \\
\hline Variety & Treatments & $\begin{array}{l}\text { Grain yield } \\
\left(\mathrm{t} \mathrm{ha}^{-1}\right)\end{array}$ & $\begin{array}{c}\text { Straw yield } \\
\left(\mathrm{tha}^{-1}\right)\end{array}$ & $\begin{array}{c}\mathrm{Zn} \text { concentration } \\
\left(\mathrm{mg} \mathrm{kg}^{-1}\right)\end{array}$ \\
\hline \multirow[t]{2}{*}{ RRI dhan49 } & $\mathrm{Zn}_{0}$ & $4.54 \mathrm{~b}$ & $4.67 \mathrm{def}$ & $12.20 \mathrm{gh}$ \\
\hline & $\mathrm{Zn}_{3}$ & $5.15 \mathrm{a}$ & $5.13 \mathrm{bcd}$ & $15.53 \mathrm{cdef}$ \\
\hline \multirow[t]{2}{*}{ BRRI dhan52 } & $\mathrm{Zn}_{0}$ & $4.02 \mathrm{c}$ & $4.41 \mathrm{ef}$ & $11.25 \mathrm{~h}$ \\
\hline & $\mathrm{Zn}_{3}$ & $4.62 \mathrm{~b}$ & $4.86 \mathrm{cdef}$ & $14.07 \mathrm{efg}$ \\
\hline \multirow[t]{2}{*}{ BRRI dhan56 } & $\mathrm{Zn}_{0}$ & $3.80 \mathrm{~cd}$ & $4.44 \mathrm{ef}$ & $12.19 \mathrm{gh}$ \\
\hline & $\mathrm{Zn}_{3}$ & $4.60 \mathrm{~b}$ & 4.90cdef & $15.19 \mathrm{cdef}$ \\
\hline \multirow[t]{2}{*}{ BRRI dhan57 } & $\mathrm{Zn}_{0}$ & $3.09 \mathrm{efg}$ & $3.47 \mathrm{~h}$ & $15.07 \mathrm{cdef}$ \\
\hline & $\mathrm{Zn}_{3}$ & $3.48 \mathrm{de}$ & $3.85 \mathrm{gh}$ & $19.09 \mathrm{a}$ \\
\hline \multirow[t]{2}{*}{ Kalizira } & $\mathrm{Zn}_{0}$ & $2.53 \mathrm{~h}$ & $4.62 \mathrm{def}$ & $14.96 \mathrm{cdef}$ \\
\hline & $\mathrm{Zn}_{3}$ & $2.66 \mathrm{gh}$ & $5.16 \mathrm{bcd}$ & $17.46 \mathrm{abc}$ \\
\hline \multirow[t]{2}{*}{ Biroin } & $\mathrm{Zn}_{0}$ & $2.93 \mathrm{fgh}$ & $5.31 \mathrm{bc}$ & $14.79 \mathrm{def}$ \\
\hline & $\mathrm{Zn}_{3}$ & $3.25 \mathrm{ef}$ & $5.91 \mathrm{a}$ & 17.04abcd \\
\hline \multirow[t]{2}{*}{ Gainja } & $\mathrm{Zn}_{0}$ & $2.98 \mathrm{fgh}$ & $5.00 \mathrm{cde}$ & $13.36 \mathrm{fgh}$ \\
\hline & $\mathrm{Zn}_{3}$ & $3.08 \mathrm{efg}$ & $5.58 \mathrm{ab}$ & $16.20 \mathrm{bcde}$ \\
\hline \multirow[t]{2}{*}{ Khirshapath } & $\mathrm{Zn}_{0}$ & $2.82 \mathrm{fgh}$ & $4.32 \mathrm{fg}$ & $16.06 \mathrm{bcde}$ \\
\hline & $\mathrm{Zn}_{3}$ & $2.90 \mathrm{fgh}$ & $4.80 \mathrm{cdef}$ & $18.38 \mathrm{ab}$ \\
\hline $\mathrm{CV}(\%)$ & & 6.87 & 6.59 & 8.90 \\
\hline Level of significance & & $*$ & $* *$ & $* *$ \\
\hline
\end{tabular}

\section{B. Grain Yield}

Grain yield of rice varieties showed significant variation due to application of $\mathrm{Zn}$ to the soil (Table III). The highest grain yield $\left(4.85 \mathrm{t} \mathrm{ha}^{-1}\right)$ was observed in BRRI dhan 49 with $3 \mathrm{~kg} \mathrm{ha}^{-1} \mathrm{Zn}$ application and the lowest $\left(2.53 \mathrm{t} \mathrm{ha}^{-1}\right)$ was in Kalizira without $\mathrm{Zn}$ application. The interaction of two levels of $\mathrm{Zn}$ with different varieties showed significant variation in grain yield of rice (Table IV). The highest grain yield (5.15 $\mathrm{t} \mathrm{ha}^{-1}$ ) was observed in BRRI dhan49 with $3 \mathrm{~kg} \mathrm{ha}^{-1} \mathrm{Zn}$ application and the lowest $\left(2.53 \mathrm{t} \mathrm{ha}^{-1}\right)$ was in Kalizira without any $\mathrm{Zn}$ application. Among the eight varieties of rice significant increase of grain yield was observed in BRRI dhan49, BRRI dhan52 and BRRI dhan56 due to application of $\mathrm{Zn}$ compared to $\mathrm{Zn}$ control treatment. In BRRI dhan52 and four local varieties, the yield increase due to $\mathrm{Zn}$ application was not significant compared to $\mathrm{Zn}$ control treatments. The percent increase in grain yield over control in modern varieties ranged from $12.6-21.1 \%$ while in local varieties it ranged from 2.8 to $10.9 \%$ (Fig.1). These findings also were in agreement with the other findings [30] [31]. All the research findings indicate a highly significant yield response was obtained from the application of $\mathrm{Zn}$. Zinc fertilization led to a significant increase in rice yield [19]. The increased yield due to $\mathrm{Zn}$ fertilization is related to its participation in various metallic enzyme reactions, regulatory functions, and auxin production [32].

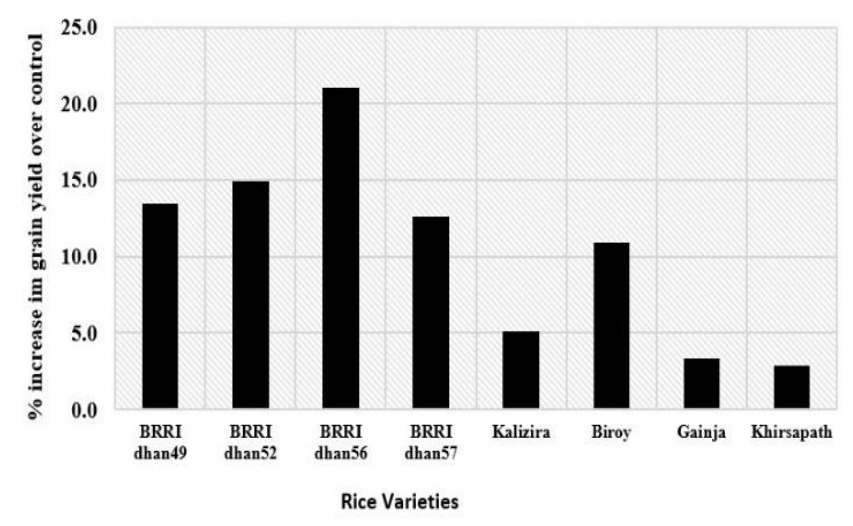

Fig. 1. Percent increase of grain yield over control for different varieties of rice

\section{Straw Yield}

Straw yield of rice showed significant increase due to soil application of $\mathrm{Zn}$ (Table III). The highest straw yield was observed in Biroin with $3 \mathrm{~kg} \mathrm{ha}^{-1} \mathrm{Zn}$ application which was statistically similar with Gainja and the lowest straw yield (3.47 $\mathrm{t} \mathrm{ha}^{-1}$ ) was observed in BRRI dhan57 without any $\mathrm{Zn}$ application (Table III). These results have conformity with the evidence of other study [33]. Higher levels of $\mathrm{Zn}$ (10 and $15 \mathrm{~kg} \mathrm{Zn} \mathrm{ha}^{-1}$ ) increased both straw and grain yields [34]-[37]. The interaction of two levels of $\mathrm{Zn}$ with different varieties showed variation in terms of straw yield (TABLE IV). The highest straw yield was observed in Biroin with $3 \mathrm{~kg} \mathrm{ha}^{-1} \mathrm{Zn}$ application which was statistically similar with Gainja and the lowest straw yield $\left(3.47 \mathrm{t} \mathrm{ha}^{-1}\right)$ was observed in BRRI dhan57 without $\mathrm{Zn}$ application.

\section{Grain-Zn Concentration}

High grain- $\mathrm{Zn}$ concentration is considered a desirable quality [38] of food grain. In terms of grain $\mathrm{Zn}$ concentration, significant variation was observed with different varieties of rice (Table III \& IV). The highest grain $\mathrm{Zn}$ concentration (19.09 $\mathrm{mg} \mathrm{kg}^{-1}$ ) was observed in BRRI dhan57 with $3 \mathrm{~kg} \mathrm{ha}^{-1}$ $\mathrm{Zn}$ application and the lowest $\mathrm{Zn}$ concentration $(11.25 \mathrm{mg} \mathrm{kg}$ $\left.{ }^{1}\right)$ was observed in BRRI dhan52 without $\mathrm{Zn}$ application. Among the eight varieties of rice, significant increase of $\mathrm{Zn}$ concentration in grain was observed in all varieties except $\mathrm{Bi}$ -

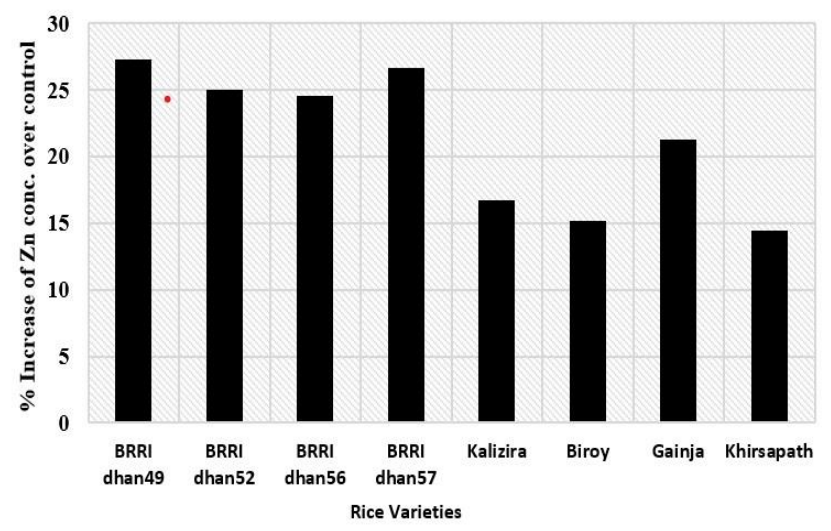

Fig. 2. Percent increase of grain $\mathrm{Zn}$ concentration over control for different varieties of rice 
-roin due to $\mathrm{Zn}$ fertilization. Application of $\mathrm{Zn}$ increased grain $\mathrm{Zn}$ contents of rice as reported by various workers [39] [40]. The percent increase in grain $\mathrm{Zn}$ concentration over control in modern rice varieties ranged from 24.3-27.3\% while in local varieties it ranged from 15.21 to $21.2 \%$ (Fig. 2). Based on percent increase in grain $\mathrm{Zn}$ concentration over control, the treatments may be ranked in order of BRRI dhan $49>$ BRRI dhan57 > BRRI dhan52 > BRRI dhan56> Gainja $>$ Kalizira $>$ Khirshapath $>$ Biroin. That indicates high yielding varieties showed significant $Z n$ enrichment in grain compared to local varieties. Higher levels of $\mathrm{Zn}$ increased yield and $\mathrm{Zn}$ content in both rice grains and straw [34], supporting the findings of the current study.

\section{CONCLUSION}

Zinc application significantly increased the grain yields of BRRI dhan49, BRRI dhan52 and BRRI dhan56. Among the eight rice varieties, significant increase of $\mathrm{Zn}$ concentration in grain was observed in all rice varieties except Biroin due to soil application of $\mathrm{Zn}$. Based on percent grain yield increase over control, the varieties may be ranked in order of BRRI dhan56 > BRRI dhan52 > BRRI dhan49 > BRRI dhan57 > Biroin > Kalizira > Gainja > Khirshapath. The highest percent increase of grain $\mathrm{Zn}$ concentration over control was obtained in BRRI dhaan 49 and the lowest one was obtained in Biroin. The application of $\mathrm{Zn}$ increased the nutritional quality of rice grain for both local and high yielding varieties.

\section{ACKNOWLEDGMENT}

The authors are grateful to the Department of Soil Science, BAU for providing the experiment and analysis facilities.

\section{REFERENCES}

[1] Kumar D, Kumar R, Singh P, Kumar P. Effect of different zinc management practices on growth, yield, protein content, nutrient uptake and economics on rice under partially reclaimed salt affected soil. Journal of Pharmacognosy and Phytochemistry. 2017;6(5):63840.

[2] Kromann P, Valverde F, Alvarado S, Vélez R, Pisuña J, Potosí B, Taipe A, Caballero D, Cabezas A, Devaux A. Can Andean potatoes be agronomically biofortified with iron and zinc fertilizers?. Plant and Soil. 2017 Feb 1;411(1-2):121-38.

[3] White PJ, Thompson JA, Wright G, Rasmussen SK. Biofortifying Scottish potatoes with zinc. Plant and soil. 2017 Feb 1;411(1-2):15165.

[4] Roohani N, Hurrell R, Kelishadi R, Schulin R. Zinc and its importance for human health: An integrative review. Journal of research in medical sciences: the official journal of Isfahan University of Medical Sciences. 2013 Feb;18(2):144.

[5] Ghoneim AM. Effect of different methods of $\mathrm{Zn}$ application on rice growth, yield and nutrients dynamics in plant and soil. Journal of Agriculture and Ecology Research International. 2016 Jan 9:1-9.

[6] Tripathi DK, Singh S, Singh S, Mishra S, Chauhan DK, Dubey NK. Micronutrients and their diverse role in agricultural crops: advances and future prospective. Acta Physiologiae Plantarum. 2015 $\mathrm{Jul} ; 37(7): 1-4$.

[7] Quijano-Guerta C, Kirk GJ, Portugal AM, Bartolome VI, McLaren GC Tolerance of rice germplasm to zinc deficiency. Field Crops Research. 2002 Jul 1;76(2-3):123-30.

[8] Sarker MM, Jahiruddin M, Moslehuddin AZ, Islam MR. Optimization of zinc and boron doses for cauliflower-maize-rice pattern in floodplain soil. Communications in Soil Science and Plant Analysis. 2019 Jul 4;50(12):1425-38.
[9] Sarker MM, Moslehuddin AZ, Jahiruddin M, Islam MR. Selection of direct, residual and cumulative doses of zinc and boron fertilizers for potato-rice-rice pattern in floodplain soil. Journal of Plant Nutrition. 2020 Jul 29; 43(20):3050-61.

[10] EFSA. Scientific opinion on arsenic in food. EFSA Journal. 2009; 7: 199.

[11] Li G, Sun GX, Williams PN, Nunes L, Zhu YG. Inorganic arsenic in Chinese food and its cancer risk. Environment international. $2011 \mathrm{Oct}$ 1;37(7):1219-25.

[12] Boonchuay P, Cakmak I, Rerkasem B, Prom-U-Thai C. Effect of different foliar zinc application at different growth stages on seed zinc concentration and its impact on seedling vigor in rice. Soil science and plant nutrition. 2013 Apr 1;59(2):180-8.

[13] Stein AJ. Global impacts of human mineral malnutrition. Plant and soil. 2010 Oct;335(1):133-54.

[14] Rahman MA, Hasegawa H, Rahman MA, Rahman MM, Miah MM. Influence of cooking method on arsenic retention in cooked rice related to dietary exposure. Science of the Total Environment. 2006 Oct 15;370(1):51-60

[15] HIES (Household Income and Expenditure Survey). Preliminary Report on Household Income and Expenditure Survey 2016. Bangladesh Bureau of Statistics (BBS), Statistics and Informatics Division (SID), Ministry of Planning, Government of The People's Republic of Bangladesh, 2016.

[16] Chandel G, Banerjee S, See S, Meena R, Sharma DJ, Verulkar SB. Effects of different nitrogen fertilizer levels and native soil properties on rice grain Fe, $\mathrm{Zn}$ and protein contents. Rice Science. $2010 \mathrm{Sep}$ $1 ; 17(3): 213-27$.

[17] Zeng Y, Zhang H, Wang L, Pu X, Du J, Yang S, Liu J. Genotypic variation in element concentrations in brown rice from Yunnan landraces in China. Environmental Geochemistry and Health. 2010 Jun 1;32(3):165-77.

[18] Halvin ZL. Soil fertility and fertilizer an Introduction to Nutrient management: Alberta agriculture and food, nutrient management planning guidedorling Kindersley. Pvt. Limited. 2005:201-7.

[19] Fageria NK, Dos Santos AB, Cobucci T. Zinc nutrition of lowland rice. Communications in Soil Science and Plant Analysis. 2011 Aug 1;42(14):1719-27.

[20] Wissuwa M, Ismail AM, Graham RD. Rice grain zinc concentrations as affected by genotype, native soil-zinc availability, and zinc fertilization. Plant and Soil. 2008 May;306(1):37-48.

[21] Impa SM, Morete MJ, Ismail AM, Schulin R, Johnson-Beebout SE. Zn uptake, translocation and grain $\mathrm{Zn}$ loading in rice (Oryza sativa L.) genotypes selected for $\mathrm{Zn}$ deficiency tolerance and high grain $\mathrm{Zn}$. Journal of experimental botany. 2013 Jul 1;64(10):2739-51.

[22] Bouis HE, Welch RM. Biofortification - a sustainable agricultural strategy for reducing micronutrient malnutrition in the global south. Crop science. 2010 Mar;50:S-20.

[23] Waters BM, Sankaran RP. Moving micronutrients from the soil to the seeds: genes and physiological processes from a biofortification perspective. Plant Science. 2011 Apr 1;180(4):562-74.

[24] Gomez KA, Gomez AA. Statistical procedures for agricultural research. John Wiley \& Sons; 1984 Feb 17.

[25] Rana WK, Kashif SR. Effect of different Zinc sources and methods of application on rice yield and nutrients concentration in rice grain and straw. Journal of Environmental and Agricultural Sciences (JEAS) ISSN. 2013; 2313:8629.

[26] Singh V, Singh V, Singh S. Effect of Zinc and Silicon on Growth and Yield of Aromatic Rice (Oryza sativa) in North-Western Plains of India. J. Rice Res. Dev. 2020;3(1):82-6.

[27] Wang YY, Wei YY, Dong LX, Lu LL, Feng Y, Zhang J, Pan FS, Yang $\mathrm{XE}$. Improved yield and $\mathrm{Zn}$ accumulation for rice grain by $\mathrm{Zn}$ fertilization and optimized water management. Journal of Zhejiang University Science B. 2014 Apr;15(4):365-74.

[28] Bodruzzaman M, Sadat MA, Meisner CA, Hossain AB, Khan HH. Direct and residual effects of applied organic manures on yield in a wheat-rice cropping pattern. In Proceedings of the 17th World Congress of Soil Science, Bangkok, Thailand 2002 Aug 14 (pp. 14-21).

[29] Maqsood M, Irshad M, Wajid SA, Hussain A. Growth and yield response of Basmati-385 (Oryza sativa L.) to $\mathrm{ZnSO} 4$ application. Pakistan Journal of Biological Sciences (Pakistan). 1999.

[30] Abbas M, Zahida TM, Uddin R, Sajjid I, Akhlaq A, Moheyuddin K, Salahuddin J, Mari AH, Panhwar RN. Effect of zinc and boron fertilizers application on some physicochemical attributes of five rice varieties grown in agro-ecosystem of Sindh, Pakistan. AmericanEurasian Journal of Agricultural \& Environmental Sciences. 2013;13(4):433-9.

[31] Sudha S, Stalin P. Effect of zinc on yield, quality and grain zinc content of rice genotypes. International journal of farm sciences. 2015;5(3):1727. 
European Journal of Agriculture and Food Sciences www.ejfood.org

[32] Sachdev P, Deb DL, Rastogi DK. Effect of varying levels of zinc and manganese of drymatter yield and mineral composition of wheat plant at maturity. Journal of Nuclear Agriculture and Biology;(India). 1988 Sep $1 ; 17(3)$

[33] Zinzala VN, Narwade AV. Effect of Zinc applications on Grain Yield Straw Yield and Harvest Index in kharif Rice (Oryza sativa L.) Genotypes. Int. J. Curr. Microbiol. App. Sci. 2019;8(11):27-35.

[34] Alwahibi MS, Elshikh MS, Alkahtani J, Muhammad A, Khalid S, Ahmad M, Khan N, Ullah S, Ali I. Phosphorus and Zinc Fertilization Improve Zinc Biofortification in Grains and Straw of Coarse vs. Fine Rice Genotypes. Agronomy. 2020 Aug;10(8):1155.

[35] Naik SK, Das DK. Evaluation of various zinc extractants in lowland rice soil under the influence of zinc sulfate and chelated zinc. Communications in soil science and plant analysis. 2010 Jan 1;41(1):122-34.

[36] Shaheen R, Samim MK, Mahmud R. Effect of zinc on yield and zinc uptake by wheat on some soils of Bangladesh. Journal of Soil Nature. 2007;1(1):07-14.

[37] Khan M, Fuller M, Baloch F. Effect of soil applied zinc sulphate on wheat (Triticum aestivum L.) grown on a calcareous soil in Pakistan. Cereal Research Communications. 2008 Dec 1;36(4):571-82.

[38] Cakmak I. Enrichment of cereal grains with zinc: agronomic or genetic biofortification?. Plant and soil. 2008 Jan;302(1):1-7.

[39] Phattarakul N, Mongon J, Rerkasem B. Variation in rice grain zinc and their response to zinc fertilizer. In 3rd international zinc symposium 2011 Oct (pp. 10-14)

[40] Zhang YQ, Deng Y, Chen RY, Cui ZL, Chen XP, Yost R, Zhang FS, Zou CQ. The reduction in zinc concentration of wheat grain upon increased phosphorus-fertilization and its mitigation by foliar zinc application. Plant and Soil. 2012 Dec;361(1):143-52. 